\title{
Implementation of the Corporate Social Responsibility Program that Supports the Regent's Vision and Mission through the Corporate Social and Environmental Responsibility Forum in Serdang Bedagai District
}

\author{
Parlinggoman O.S ${ }^{1}$, Humaizi ${ }^{2}$, Munir Tanjung ${ }^{3}$ \\ ${ }^{1,2,3}$ Universitas Sumatera Utara, Indonesia \\ Corresponding Author: Parlinggoman O.S
}

DOI: https://doi.org/10.52403/ijrr.20220181

\begin{abstract}
The purpose of this study was to identify and analyze the implementation of the corporate social responsibility program that supports the Regent's vision and mission through the Corporate Social and Environmental Responsibility Forum in Serdang Bedagai District. This study used descriptive qualitative method. The research location in this study was in Serdang Bedagai District in North Sumatra Province. Data collection techniques used in this study were observation, interviews, and documentation. The data analysis technique used in this research is data reduction, data presentation, and conclusion drawing. The results of the study show that the programs and activities of corporate social responsibility implemented in Serdang Bedagai District are partly not in line with the vision and mission of Serdang Bedagai District, this is because each company has a strategic plan and main tasks and functions of each company, this is the obstacle in carrying out corporate social responsibility activities.
\end{abstract}

Keywords: Corporate Social Responsibility,

Vision, Mission, Corporate Social and

Environmental Responsibility

\section{INTRODUCTION}

The concept of corporate social responsibility itself has been known since the early 1970s, which is generally defined as a collection of policies and practices related to stakeholders, values, compliance with legal provisions, community appreciation, the environment, and the commitment of the business community to contribute to sustainable development. The corporate social responsibility program is not only a creative activity of the company and is not limited to compliance with legal regulations. Corporate social responsibility program is one of the social activities that must be carried out by companies operating in Indonesia. In connection with the demands and needs for a corporate social responsibility program which is one of the obligations that must be carried out by companies in accordance with the contents of article 74 of the new Limited Liability Company Law. This law was ratified in the plenary session of the House of Representatives.

There are two laws which emphasize that the corporate social responsibility program is an obligation for Limited Liability Companies, namely to emphasize on corporate social responsibility, namely Law No. 40 of 2007 concerning Limited Liability Companies Article 74 and Law No. 25 of 2007 concerning Investment Articles 15, 17 and 34 .

With this law, industry or companies are obliged to implement corporate social 
Parlinggoman O.S et.al. Implementation of the corporate social responsibility program that supports the regent's vision and mission through the corporate social and environmental responsibility forum in Serdang Bedagai District.

responsibility programs, but this obligation is not an burdensome burden for the company. It should be remembered that the development of a country is not only the responsibility of the government and industry, but every human being must play an active role in realizing social welfare and managing the quality of life of the community. The company's role is to encourage economic growth taking into account environmental factors.

Since the promulgation of the legislation on corporate social responsibility itself, there are more and more companies or agencies competing to carry out imagery to maintain reputation and business continuity. Because without a good reputation, it is impossible to get a positive response from the community. Corporate image is an important axiom for companies to be able to survive and develop continuously towards the peak of success. And the way that is taken to shape the image and maintain the sustainability of the company, one of which is through the corporate social responsibility program, because it cannot be denied that the image of a company will be made in such a way and synergized with the corporate social responsibility program, so that the company can protect it from a crisis of public trust.

Corporate social responsibility in Serdang Bedagai District itself has a large enough impact in creating development in Serdang Bedagai District, it can be seen by the number of companies in Serdang Bedagai District. By collaborating between the government and companies through the Corporate Environmental Social Responsibility Forum which is a forum for bridging between the government and companies or the private sector in the implementation of corporate social responsibility programs in Serdang Bedagai District which is regulated in Serdang Bedagai Regent Regulation Number 17 of 2019 Regarding Guidelines for the Implementation of Corporate Social and Environmental Responsibility in Serdang Bedagai District.
Serdang Bedagai District has a vision and mission to achieve sustainable development. In achieving the vision and mission of the Regent of Serdang Bedagai, certain steps will be taken, such as through activities rather than corporate social responsibility, with the use of corporate social responsibility programs, therefore the company and local government synergize in achieving development goals in Serdang Bedagai District.

The purpose of this study was to identify and analyze the implementation of the corporate social responsibility program that supports the Regent's vision and mission through the Corporate Social and Environmental Responsibility Forum in Serdang Bedagai District.

\section{LITERATURE REVIEW \\ Implementation}

Grindle (1980:7) states that implementation is a general process of administrative action that can be investigated at a certain program level. Meanwhile, Van Meter and Horn state that policy implementation is an action taken by the government and the private sector both individually and in groups that are intended to achieve goals. Grindle (1980:7) adds that the implementation process will only begin when the goals and objectives have been set, the activity program has been structured and the funds are ready and have been channeled to achieve the goals.

According to Lane, implementation as a concept can be divided into two parts. First, implementation $=\mathrm{F}$ (intention, output, outcome). According to this definition, implementation is a function consisting of aims and objectives, results as products and results from consequences. Second, implementation is a functional equation of implementation $=\mathrm{F}$ (policy, formator, implementor, initiator, time). The main emphasis of these two functions is on the policy itself, then the results achieved and implemented by the Implementor within a certain period of time (Sabatier, 1986:2148). 
Parlinggoman O.S et.al. Implementation of the corporate social responsibility program that supports the regent's vision and mission through the corporate social and environmental responsibility forum in Serdang Bedagai District.

Policy implementation links the policy objectives and their realization with the results of government activities. This is in accordance with the views of Van Meter and Horn that the task of implementation is to build a network that allows the goals of public policy to be realized through the activities of government agencies involving various interested parties.

\section{Corporate Social Responsibility}

Many terms about corporate responsibility, in legislation use social and environmental responsibility or corporate social responsibility or sometimes people also call it business social responsibility or corporate citizenship or corporate responsibility or business citizenship. The terms above have the same meaning and are often used to refer to the meaning of corporate social responsibility. Even though corporate social responsibility is still very small, it has been strictly regulated in Indonesia, namely in Law Number 40 of 2007 concerning Limited Liability Companies, Law Number 25 of 2007 concerning Investment, and Regulation of the Minister of State for State-Owned Enterprises Number Per- 5/MBU/2007 concerning BUMN Partnership Program with Small Business and Community Development Program, specifically for BUMN companies. After that, corporate social responsibility was included again in Law no. 40 of 2007 concerning Limited Liability Companies. Article 74 paragraph (1)of this Law states that companies that carry out their business activities in the field of and or related to natural resources are obliged to carry out social and environmental responsibilities. Paragraph (2)of this article states that the obligation is calculated as a company expense whose implementation is carried out with due regard to propriety and fairness. Furthermore, paragraph (3)states that companies that do not carry out the obligations as referred to in paragraph (1)will be subject to sanctions in accordance with the relevant laws and regulations. Then paragraph (4) states that further provisions regarding social and environmental responsibility are regulated by government regulations. There are two types of corporate social responsibility concepts, namely in a broad sense and in a narrow sense. Corporate social responsibility in a broad sense is closely related to the goal of achieving sustainable economic activities. The sustainability of economic activities is not only related to social responsibility but also to the company's accountability to society and the nation as well as the international community.

According to Widjaja and Yeremia (2008), corporate social responsibility is a form of cooperation between companies (not only limited liability companies) with all things that directly or indirectly interact with the company to ensure the existence and sustainability of the company's business (sustainability). This understanding is the same as social and environmental responsibility, which is the company's commitment to participate in sustainable economic development in order to improve the quality of life and the environment that is beneficial, both for the company itself, the local community, and society in general (Widjaja and Yani, 2006). According to the 2007 Limited Liability Company Law, the definition of corporate social responsibility in Article 1 point 3 states that social and environmental responsibility is the company's commitment to participate in sustainable economic development in order to improve the quality of life and the environment that is beneficial, both for the company itself, the local community, and the community. society in general.

\section{Development}

According to Salim sustainable development aims to improve people's welfare, to meet human needs and aspirations. Sustainable development is essentially aimed at seeking equal distribution of development between generations, both now and in the future. 
Parlinggoman O.S et.al. Implementation of the corporate social responsibility program that supports the regent's vision and mission through the corporate social and environmental responsibility forum in Serdang Bedagai District.

From the economic point of view, Fauzi (2004) there are at least three main reasons why economic development must be sustainable. The first concerns moral reasons. The current generation enjoys goods and services produced from natural resources and the environment, so it is morally necessary to pay attention to the availability of these natural resources for future generations. The moral obligation includes not extracting natural resources that can damage the environment, which could deprive future generations of opportunities to enjoy the same services. Second, regarding ecological reasons, for example, biological diversity has a very high ecological value, therefore economic activities should not be directed at the use of natural resources and the environment alone, which in the end can threaten ecological functions. The third factor, which is the reason for the need to pay attention to the sustainability aspect is economic reasons. The reason from the economic side is that there is still debate because it is not known whether economic activity so far has or has not met the sustainability criteria, as we know, that the dimension of sustainable economy itself is quite complex, so that often the aspect of sustainability from the economic side is only limited to measuring welfare between people generation.

\section{RESEARCH METHODS}

The definition of research is an organized investigation, or a careful and critical investigation in finding facts to determine something (Pandiangan et al., 2021). The word research is a translation of the word research which comes from English. The word research consists of two words, namely re which means to return and to search which means to search (Pandiangan, 2015). So it can be concluded that the meaning of research is to seek back a knowledge. The purpose of the research is to change the generally accepted conclusions, as well as to change opinions with the new application of these opinions.
A research using the scientific method is called scientific research.

This study used descriptive qualitative method. This method focuses on observation and natural atmosphere. Researchers go directly to the field and act as observers, researchers make behavioral categories, observe symptoms and record them in an observation book. And researchers go into the field without being burdened or directed by theory, researchers are free to observe the object, explore and find new insights throughout the research (Pandiangan, 2018).

The research location in this study will be conducted in Serdang Bedagai District in North Sumatra Province. The reason the researchers chose this location is because in Serdang Bedagai District there are several large companies such as PT. Socfindo, PT. PN Adolina, as well as other companies where the company is quite aggressive in corporate social activities which are expected to support the development of Serdang Bedagai District through the Regent's vision and mission.

Data collection techniques used in this study were observation, interviews, and documentation. Observation is an activity to get the information needed to present a real picture of an event or events to answer research questions. The interview method used in this research is in-depth interviews. Where the researchers conducted direct and in-depth interviews aimed at informants with draft questions that were prepared and adapted to the existing problem formulation (Pandiangan et al., 2018). This method is a way of collecting data that produces important notes related to the problem under study so that complete, valid, and not based on estimates data will be obtained by taking data that already exists and is available in document records.

The data analysis technique used in this research is data reduction, data presentation, and conclusion drawing (Tobing et al., 2018). The data analysis techniques used in this study are: 
Parlinggoman O.S et.al. Implementation of the corporate social responsibility program that supports the regent's vision and mission through the corporate social and environmental responsibility forum in Serdang Bedagai District.

\section{Data Reduction}

The data obtained from the field is quite large, therefore it is recorded in detail and thoroughly. For this reason, it is necessary to analyze data through data reduction. Reducing data means summarizing, selecting the main things, focusing on the main things, focusing on the things that are important, look for themes and patterns and discard the unnecessary. Thus the data that has been reduced will provide a clearer picture and facilitate further data collection.

\section{Data Presentation}

Data that has been compiled from the results of data reduction, is then presented in the form of narrative text. Easy to understand presentation of data is the main way to analyze valid qualitative data.

\section{Conclusion Drawing}

The initial conclusions raised are still temporary and will change if no strong evidence is found to support the next stage of data collection. But if the conclusions found at the beginning are supported by valid and consistent evidence when in the field to collect data, then the conclusions drawn are credible conclusions so that with this conclusion it is hoped that new findings that did not exist previously exist. The findings can be in the form of descriptions. or description of an object that was previously unclear, so that after research it becomes clear.

\section{RESULT}

\section{Geographical Location and Condition}

Geographically, Serdang Bedagai District is in the position of 03001'2.5" 03046'33" North Latitude and 98044'22" 99019'01" East Longitude.

Serdang Bedagai District is geographically very strategic (geostrategic) because:

1. Close to the Strait of Malacca, which is one of the most densely populated waters in the world.
2. Close to the capital city of North Sumatra Province, namely Medan City.

3. Passed by the construction of the Medan-Tebing Tinggi toll road.

4. There is a growth triangle cooperation between Indonesia-Malaysia-Thailand (IMT-GT).

In addition, Serdang Bedagai District is also a Sumatra crossing route located on the east coast of the island of Sumatra. Serdang Bedagai District is a mobility access point from or to Medan City, from or to Tebing Tinggi City. The administrative location flanked by the two cities is the biggest factor in supporting the development of the Serdang Bedagai District area.

The potential geographical location and landscape conditions of Serdang Bedagai District which are quite diverse are also supported by the potential of natural resources which are quite abundant, including: marine resources, water resources, agriculture, plantations, fisheries, forestry, mining, and tourism.

\section{Topography}

Serdang Bedagai District is located on the East Coast of North Sumatra and is generally located at an altitude of 0-500 m above sea level (asl) with a coastline of 55 $\mathrm{km}$ and 1 (one) outermost island, namely Berhala Island. The division of the Serdang Bedagai District based on elevation can be distinguished as follows:

a. Altitude 0-10 meters above sea level covering an area of 66,506.75 ha (34.63\%) of the total area of Serdang Bedagai District, located in several subdistricts except Kotarih and Sipispis Sub-District.

b. Altitude 11-50 mdpl covering an area of $117,522.74$ ha $(61.20 \%)$, found in almost all sub-districts.

c. An altitude of 51-500 mdpl covering an area of $8,007.68$ ha $(4.17 \%)$ is located in Kotarih and Sipispis Sub-District. 
Parlinggoman O.S et.al. Implementation of the corporate social responsibility program that supports the regent's vision and mission through the corporate social and environmental responsibility forum in Serdang Bedagai District.

\section{Geology}

Geologically, the soil structure in Serdang Bedagai District can be divided into 5 (five) types, namely:

1. Ordo inceptisol which spreads in almost all sub-districts.

2. Ordo oxisol is found in the Districts of Dolok Masihul, Sipispis, Tebing Syahbandar, Tebing Tinggi, and Serbajadi.
3. Ordo ultisol is located in the Districts of Kotarih, Silinda, Sipispis, Bintang Bayu, and Serbajadi.

4. Ordo entisol in Pantai Cermin District, Tanjung Beringin, and Mengkudu Bay.

5. Histosol Order in Bandar Khalifah District, Mengkudu Bay, Cermin Beach and Perbaungan.

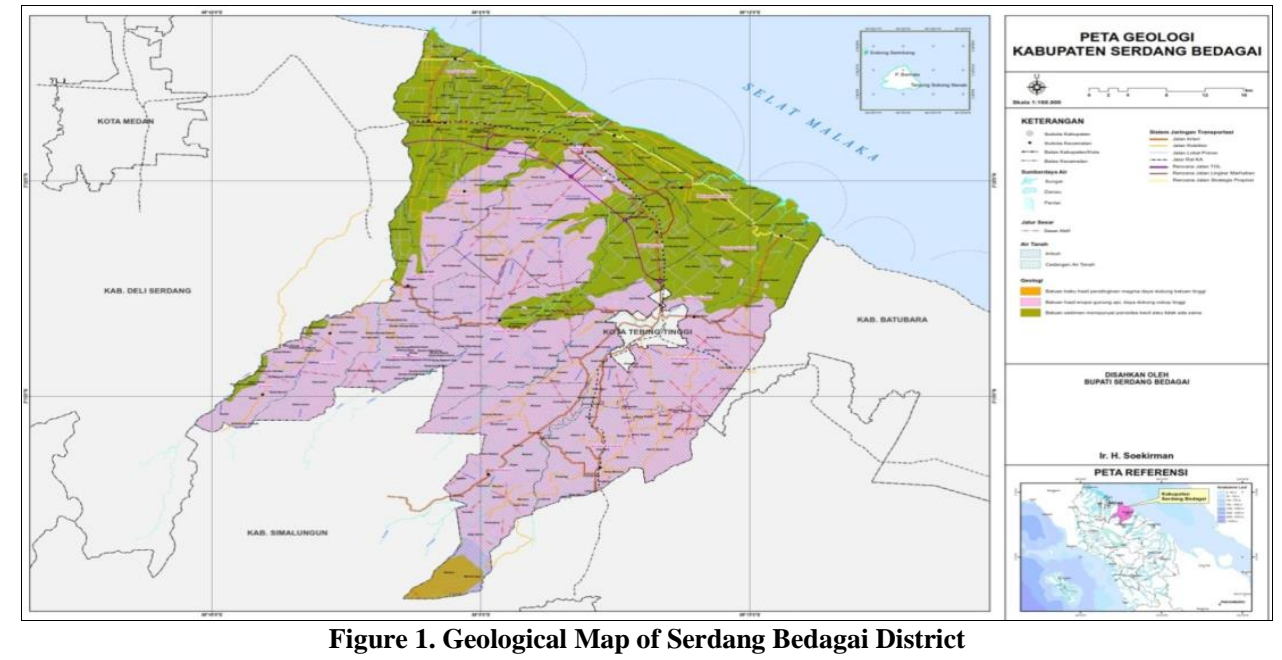

In addition, Serdang Bedagai District has 3 (three) rock types located in 3 (three) sub-regions, namely:

1. Igneous rock resulting from magma cooling, the carrying capacity of high rock is scattered in coastal areas such as in Pantai Cermin District, Perbaungan, Teluk Mengkudu, Tanjung Beringin, Sei Bamban, Bandar Khalipah, and Tebing Tinggi.

2. Rocks resulting from volcanic eruptions, carrying quite high carrying capacity are scattered in the Districts of Pegajahan, Sei Rampah, Serba Jadi, Bintang Bayu, Kotarih, Silinda, Dolok Masihul, Tebing Syahbandar, Dolok Merawan, and Sipispis.

3. Sedimentary rocks with the same small or no proportions, are scattered in parts of Sipispis District.

\section{Hydrology}

Serdang Bedagai District has 5 (five) watersheds, namely Snake Watershed, Sialang Buah Watershed, Bedagai
Watershed, Padang Watershed, and Hapal Watershed with 24 rivers. The longest rivers are the Padang River and the Bah Hilang River with a length of $25 \mathrm{~km}$ each, while the shortest rivers are the Mendaris River and Sei Rampah River with a length of $5 \mathrm{~km}$ each. The river with the widest surface is also the Padang River, which is $75 \mathrm{~m}$ while the river with the smallest surface is the Hitam River at $7 \mathrm{~m}$. In addition, the river with the largest maximum discharge is also the Padang River, which is $89.4 \mathrm{~m} 3 / \mathrm{s}$, while the river with the smallest maximum discharge is the Hitam River, which is 3.33 $\mathrm{m} 3 / \mathrm{s}$. A clearer picture of the condition of 24 large and small rivers in Serdang Bedagai District in 2020.

The condition of the river in Serdang Bedagai District has the potential to be developed as a source of drinking water, irrigation, flood control, and support tourism, agriculture, and freshwater fisheries activities.

In addition, there are 5,925.05 ha of swamp/peat areas, namely the Belidahan 
Parlinggoman O.S et.al. Implementation of the corporate social responsibility program that supports the regent's vision and mission through the corporate social and environmental responsibility forum in Serdang Bedagai District.

Swamp Area in Sei Rampah District, the Kayu Besar Swamp Area in the Bandar Khalipah District, the Kendit Swamp Area in the Tebing Tinggi District and the Bogak Besar Swamp Area in the Mengkudu Bay District.

\section{Present Condition}

The results of the study show that the programs and activities of corporate social responsibility implemented in Serdang Bedagai District are partly not in line with the vision and mission of Serdang Bedagai District, this is because each company has a strategic plan and main tasks and functions of each company, this is the obstacle in carrying out corporate social responsibility activities. Therefore, the current government through the corporate social and environmental responsibility forum is expected to be able to cooperate in all corporate social responsibility activities and programs to align with the vision and mission of Serdang Bedagai District.

With the implementation of corporate social responsibility programs and activities in Serdang Bedagai District, it must be in line with the Vision and Mission of Serdang Bedagai District, this is so that synergistic development between the private sector and the government is created where corporate social responsibility aims at creating all aspects of development and strengthening the economy for the people of the district. Serdang Bedagai to be more prosperous. For this reason, several corporate social responsibility programs and activities have been implemented that support the Vision and Mission of Serdang Bedagai District.

The Government of Serdang Bedagai District through corporate social responsibility on the main priority is regarding the river, where we know Serdang Bedagai District some areas have a lot of river flow and if there is high enough rainfall in some areas where there is less infiltration river flow, flooding will occur. It is hoped that with the company's assistance through corporate social responsibility funds related to river dredging, especially on the Sei Rampah river, which is a flood customer if there is a fairly high rainfall. It is hoped that the implementation of this corporate social responsibility activity can prevent the occurrence of flood problems that are prone to occur in several areas of Serdang Bedagai District.

Several companies in Serdang Bedagai District have agreed in terms of procedures and provisions from each company that will provide corporate social responsibility assistance through the corporate social and environmental responsibility forum with an extension of the Serdang Bedagai District government, which is expected to solve this problem soon.

Currently, the corporate social responsibility program that provides many impacts and benefits is the scholarship education program, where every year several people who are selected with the best grades during their education at school will be given scholarships. Where every year it is given to children who excel, which later can continue their education at some of the best universities in Indonesia.

For prospective students and students receiving scholarships with an amount that has been determined based on procedures from the company, they will be given dependents, both monthly and per semester, so that in carrying out their education they are more enthusiastic and are expected to further improve the quality of their learning later while attending education out there. Through this activity or program, it strongly supports the goals and vision and mission of the regent, namely in improving human resources in Serdang Bedagai District so that the quality and quality of human resources is increasing, this is evidenced by the presence of several students who have the best grades during their education at the university.

What is most felt by the community and also the government of Serdang Bedagai District is the construction of public facilities infrastructure in the form of 
Parlinggoman O.S et.al. Implementation of the corporate social responsibility program that supports the regent's vision and mission through the corporate social and environmental responsibility forum in Serdang Bedagai District.

road construction, concrete, bus stops, as well as several other types of public facilities that can be felt directly by the community in several areas of the Serdang Bedagai District company.

The construction of these public facilities is also very helpful both in the use of the Serdang Bedagai District of regional revenue and expenditure budget for development both in the form of facilities and infrastructure. The community in several areas within the company's environment is greatly helped by the provision of facilities rather than corporate social responsibility activities itself so that it really helps the community's economy and also help them access the family's economic livelihood.

\section{CONCLUSION AND SUGGESTION}

The results of the study show that the programs and activities of corporate social responsibility implemented in Serdang Bedagai District are partly not in line with the vision and mission of Serdang Bedagai District, this is because each company has a strategic plan and main tasks and functions of each company, this is the obstacle in carrying out corporate social responsibility activities.

The suggestion in the research is that the corporate social responsibility/corporate social and environmental responsibility Forum is expected to be more active in assisting the process of implementing corporate social responsibility programs and can also direct and also provide input to companies so that the achievements of corporate social responsibility programs can run well and are also in accordance with the vision and mission of Serdang District be different. The company is also expected to be able to provide reports related to corporate social responsibility so that it can be recorded by the government so that the use of corporate social responsibility funds in Serdang Bedagai District is realized properly.

Acknowledgement: None

\section{Conflict of Interest: None}

\section{Source of Funding: None}

\section{REFERENCES}

1. Fauzi, Akhmad. (2004). Ekonomi Sumber Daya Alam dan Lingkungan: Teori dan Aplikasi. Jakarta: PT Gramedia Pustaka Utama.

2. Grindle, Merilee S. (1980). Politics and Policy Implementations in the Third Word. New Jersey: Princetown University Press.

3. Pandiangan, Saut Maruli Tua. (2015). Analisis Lama Mencari Kerja Bagi Tenaga Kerja Terdidik di Kota Medan. Skripsi. Medan: Fakultas Ekonomi dan Bisnis, Program Studi Ekonomi Pembangunan, Universitas Sumatera Utara. https://www.academia.edu/52494724/Analis is_Lama_Mencari_Kerja_Bagi_Tenaga_Ker ja_Terdidik_di_Kota_Medan.

4. Pandiangan, Saut Maruli Tua. (2018). Analisis Faktor-faktor yang Mempengaruhi Penawaran Tenaga Kerja Lanjut Usia di Kota Medan. Tesis. Medan: Fakultas Ekonomi dan Bisnis, Program Studi Ilmu Ekonomi, Universitas Sumatera Utara. http://repositori.usu.ac.id/bitstream/handle/1 23456789/10033/167018013.pdf?sequence= 1\&isAllowed=y.

5. Pandiangan, Saut Maruli Tua, Rujiman, Rahmanta, Tanjung, Indra I., Darus, Muhammad Dhio, \& Ismawan, Agus. (2018). An Analysis on the Factors which Influence Offering the Elderly as Workers in Medan. IOSR Journal of Humanities and Social Science (IOSR-JHSS), 23(10), 76-79. DOI: 10.9790/0837-2310087679.

6. Pandiangan, Saut Maruli Tua, Resmawa, Ira Ningrum, Simanjuntak, Owen De Pinto, Sitompul, Pretty Naomi, \& Jefri, Riny. (2021). Effect of E-Satisfaction on Repurchase Intention in Shopee User Students. Budapest International Research and Critics Institute-Journal, 4(4), 77857791.

DOI: https://doi.org/10.33258/birci.v4i4.2697.

7. Sabatier, Paul. (1986). Top Down and Bottom Up Approaches to Implementation Research. Journal of Public Policy, 6.

8. Salim, Emil. (1990). Konsep Pembangunan Berkelanjutan. Jakarta.

9. Tobing, Murniati, Afifuddin, Sya'ad, Rahmanta, Huber, Sandra Rouli, 
Parlinggoman O.S et.al. Implementation of the corporate social responsibility program that supports the regent's vision and mission through the corporate social and environmental responsibility forum in Serdang Bedagai District.

Pandiangan, Saut Maruli Tua, \& Muda, Iskandar. (2018). An Analysis on the Factors Which Influence the Earnings of Micro and Small Business: Case at Blacksmith Metal Industry. Academic Journal of Economic Studies, 5(1), 17-23. https://www.ceeol.com/search/articledetail?id=754945.

10. Widjaja, Gunawan \& Yani, Ahmad. (2006). Seri Hukum Bisnis Perseroan Terbatas. Jakarta: PT RajaGrafindo Persada.

11. Widjaja, Gunawan \& Yeremia, Ardi Pratama. (2008). Risiko Hukum dan Bisnis
Perusahaan Tanpa CSR. Jakarta: Forum Sahabat.

How to cite this article: Parlinggoman O.S, Humaizi, Munir Tanjung. Implementation of the corporate social responsibility program that supports the regent's vision and mission through the corporate social and environmental responsibility forum in Serdang Bedagai District. International Journal of Research and Review. 2022; 9(1): 705-713. DOI: https://doi. org/10.52403/ijrr.20220181 